Science Life

\title{
THE SOLITARY ROAD OF ENTOMOLOGIST JËKABS CINOVSKIS (3 February 1906 - 8 September 1984)
}

\author{
Zigrīda Čudare
}

\begin{abstract}
There are people who walk a solitary road. They do not stop when tired, but gather their strength and go on, creating a road to follow. They do their work quietly as well. Such a person was the Corresponding Member of the Latvian Academy of Sciences Dr. biol. Jēkabs Cinovskis. Much has been accomplished on his road, and, what is especially important, a new original direction of scientific work has been established in Latvia. Currently the research spectrum created by Jēkabs Cinovskis is topical and acknowledged in many countries worldwide.
\end{abstract}

\section{TIDE OF LIFE - A CHARACTERISTIC BEGINNING FOR MANY LATVIAN YOUTHS AT THAT TIME}

Jēkabs Cinovskis was born in "Ciņi", Kuldīga District, Alsunga civil parish. There he learnt not only the pungency of work, but also the joy and pride of his mother and father's praise for his well-accomplished work. This established confidence and understanding for the rest of his life that work must be done well.

J. Cinovskis studied in Alsunga Secondary School, later in Liepāja Gymnasium. He continued his studies at the Rìga Teachers' Training Institute. After graduating, he moved on to study at the University of Latvia, Faculty of Mathematics and Science, specialising in Zoology.

During summer, in order to raise money for studies, Jēkabs Cinovskis collected folklore materials. His collection was housed by the Institute of Literature, Folklore and Art of the University of Latvia (before 2006 - of the Latvian Academy of Sciences). Perhaps it is this knowledge of his nation that later helped him to choose a working field that was connected with protection of nature-friendly plants, based on research in insects and their pathogen cells.

\section{CHANGES CAUSED BY THE WAR}

In 1940, Jēkabs Cinovskis graduated from the University of Latvia and remained as a member of the faculty in order to continue the scientific work he had begun during his studies. The Second World War put an end to this, and since J. Cinovskis did not support violence and avoided mobilisation in the army, he suffered the consequences, but managed to survive.

After the war and until 1947, J. Cinovskis worked in the pedagogical field, also for some time in the famous $1^{\text {st }}$ Gymnasium. For a short time he also worked as a junior research associate at the Institute of Zootechnics and Veteri- nary Science of the Academy of Sciences of the Latvian Soviet Socialistic Republic (SSR).

\section{RETURN TO RESEARCH}

In April 1951, the Institute of Biology of the Academy of Sciences of the Latvian SSR was established (currently the Institute of Biology of the University of Latvia). Jēkabs Cinovskis started to work there as a junior research associate.

For a short period he searched for his preferable field of work, focusing on various zoology fields, even in research of Lake Lielauce zoobenthos. Consequently, the research direction prevailed that he had started during his studies, where the main research object was insects.

\section{ESTABLISHED SCIENTIFIC WORK DIRECTIONS IN LATVIA}

In 1953, Jēkabs Cinovskis defended his doctoral dissertation "Phytophaga of the Latvian SSR" and was awarded the Candidate of Science degree in biology. During this year, he established the Animal Cytology Laboratory in the institute, which he headed until 1976 - during the period of his active scientific work. In these years, he established a new research direction in Latvia — insect cytology (Cinovskis, 1955; 1956; Циновский, 1958a; 1958b; 1964; 1967; Циновский и Егина, 1959; 1961a; 1961b; 1961c). It was a rare and original research field not only in the Baltic States, but also worldwide. In recent years, persons continuing in the field have made valuable contributions in research using cytological methods. There are not too many scientists who can reach above traditional methods and explain interaction mechanisms on the cell level.

During this time, J. Cinovskis published a monograph Insects in Latvia. Sawflies and Siricidae (Циновский, 1953). In this work he described more than 400 species, their dis- 


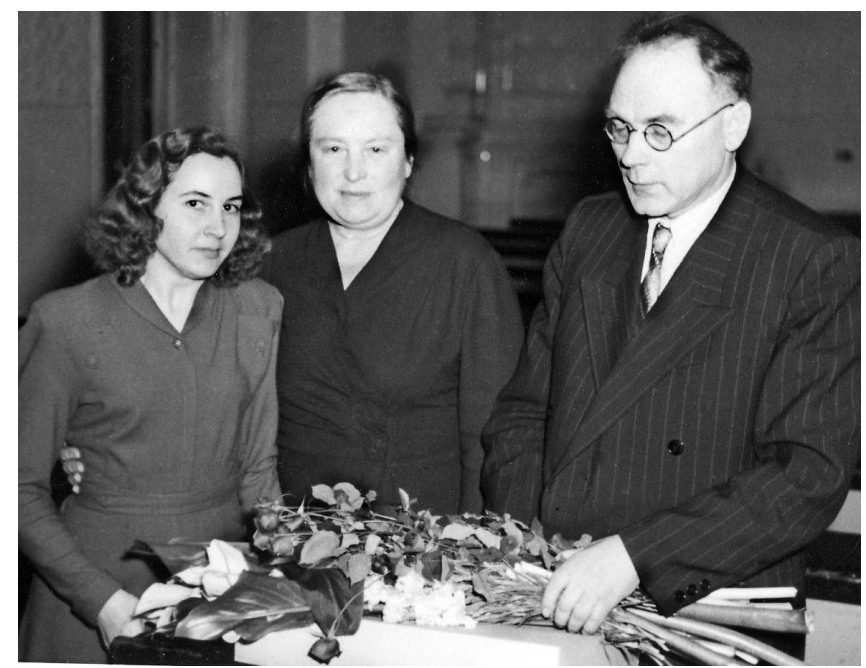

Jēkabs Cinovskis, having received the Candidate of Science degree in biology, with Klāra Jēgina, his wife and laboratory assistant (on the left) (1953; from K. Jēgina's personal archives).

tribution, economic importance and control. Even today this research has not lost its significance.

In 1959, Jēkabs Cinovskis defended his second-level doctoral dissertation Maijvaboḷu kāpuru iekūņošanās biologiskie pamati [Biologic backgrounds of the cockchafer grub pupation] and was awarded a Doctoral degree in biology. While working with the dissertation theme, he discovered a new cell group - secondary apical cells, which are important in the development of gametal cells.

In the late 1950s, J. Cinovskis lead the foundation for application of biological plant protection in Latvia, in the study of egg parasite trichogram application for apple and leaf roller, and forest pest control (Cinovskis et al., 1966; Cinovskis un Stare, 1975). In 1965, he started investigation of entomopathogens - fungus, bacterium, baculovirus, and ticks of prey (Егина и др., 1972; Cinovskis u.c., 1974; Егина и др. 1976; 1977; Циновский и др., 1977). Based on his suggestion, the Horticultural Station of Ogre established a laboratory for trichogram multiplication. A survey of agricultural crops was performed to investigate the damage caused by pathogens.

The work of Jēkabs Cinovskis was highly appreciated. In 1966, he was elected as a corresponding member of the Academy of Sciences of the Latvian SSR. Over the years the scientist's health worsened, and from 1976 until his retirement in 1982, he worked as a senior scientific associate - adviser.

Jēkabs Cinovskis was a realist, who all his life maintained a close connection to the countryside. His scientific work was connected to herb pest control. His research was a combination of ecological and biological research, as well as of interaction processes on the cell level. The fundamental research consequently could be applied in practice.

Jēkabs Cinovskis deserves merit for educating agricultural workers. During several years (1957-1966), he organised visiting sessions, where he informed local specialists about

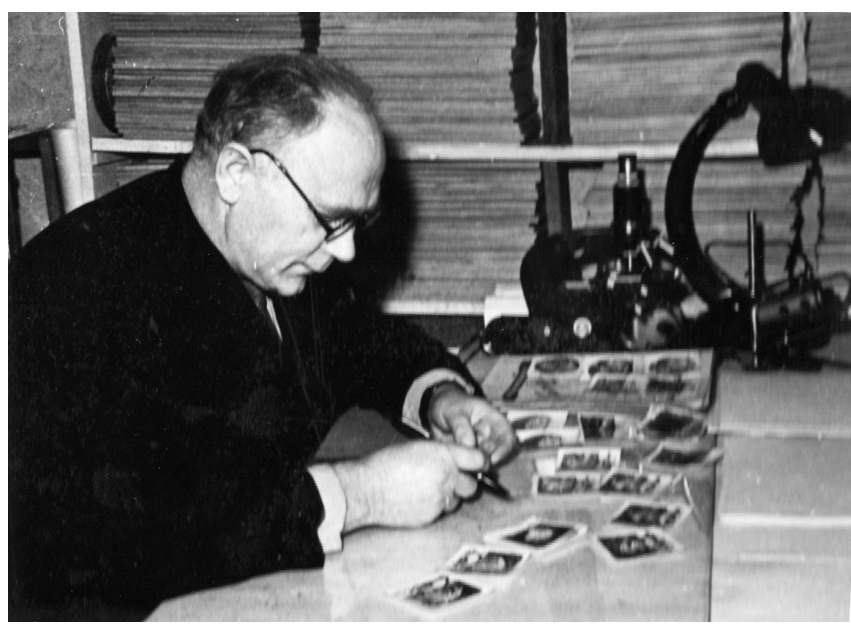

J. Cinoskis tests eggs of important antagonists, egg parasitoids Trihogramma evanescens (1966) (from K. Jēgina's personal archives).

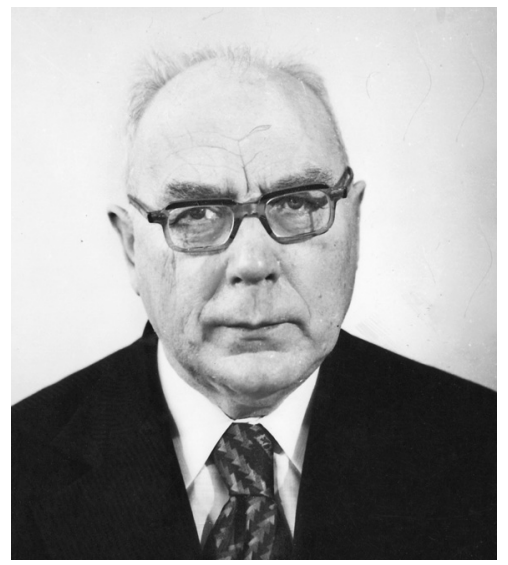

Jèkabs Cinovskis in the 1970s (from K. Jēgina's personal archives).

plant pests and their control in various farms. He has published countless popular publications in various newspapers and magazines.

He greatly contributed to the development of biology and the training of new specialists. During his life, he wrote more than 200 scientific publications. He was the editor of several publications, including Fauna of Latvia USSR in four volumes.

\section{RESULTS OF DETERMINED WORK}

Jēkabs Cinovskis was one of the leading zoologists in Latvia, a person with admirable sense of responsibility. He felt responsible for the laboratory as a whole, as well as for each worker individually. His assistance as a dissertation supervisor was greatly appreciated. He was not afraid of practical work, taking part in experiments; he was co-author only in publications in which he invested his share of the work.

There are only a few countries in the world where the basis of plant protection is research of interaction processes on the cell level. It was exactly this feature that ensured the validity and originality of the work performed by scientists in Latvia. Jēkabs Cinovskis was notable for his originality of scientific approach and ability to understand observation on a deeper and wider level. 


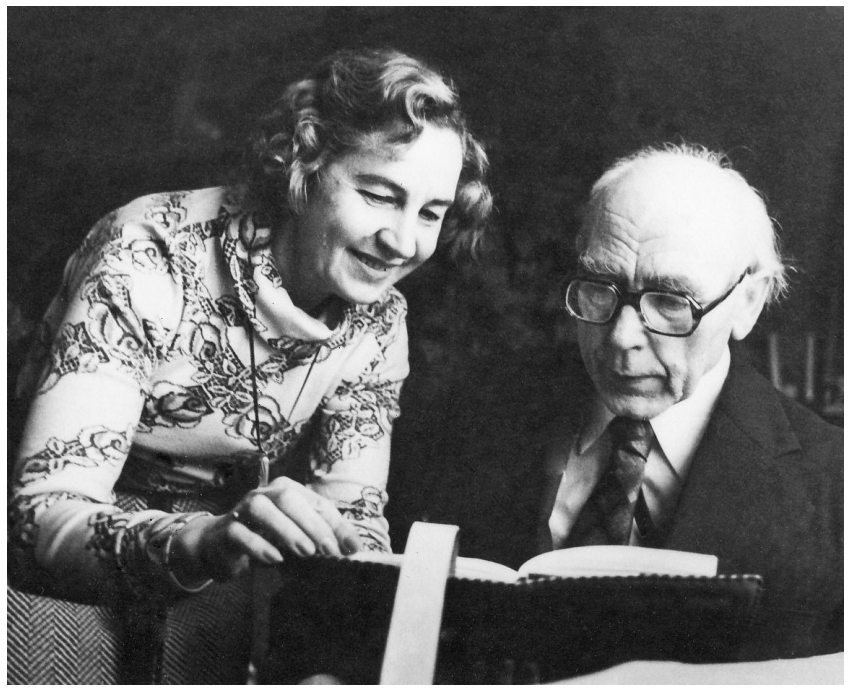

Jēkabs Cinovskis on his 75th anniversary (in 1981) and Klāra Jēgina (from K. Jēgina's personal archives).

Years are passing by, but the contribution remains. Interestingly — the widely available present-day information only raises the importance of Jēkabs Cinovskis' contribution.

\section{REFERENCES}

Cinovskis, J. (1955). Materiāli par maijvaboḷu ekoloğiju un to apkarošanu Latvijas PSR [Materials on cockchafer ecology and their abatement in Latvian SSR]. Latvijas PSR Zinātnu Akadēmijas Vēstis, Nr. 3, 87-98 (in Latvian).

Cinovskis, J. (1956). Jauna metode maijvaboḷu kāpuru iekūṇošanās prognozes uzstādī̌sanai [A new method of prognostication on cockchafer grub pupation]. Latvijas PSR Zinātņu Akadēmijas Vēstis, Nr. 4, 61-66 (in Latvian).

Cinovskis, J., Cibuḷska, A., Šilova, M. (1966). Kartupeḷu lapgrauzis jeb Kolorado vabole [Potato Beetle or Colorado Potato Beetle]. Rīga: Zinātne. 47 lpp. (in Latvian).

Cinovskis, J., Čudare, Z., Jēgina, K., Petrova, V., Strazdina, A. (1974). Sēnes Entomophothra thaxteriana Petch izmantošana ābeḷu laputu apkarošanā. [Entomophthoral fungi Entomophothra thaxteriana Petch in pest control of the aphid apple]. Latvijas PSR Zinātnu Akadēmijas Vēstis, Nr. 7, 33-36.

Cinovskis, J., Stare, A. (1975) Trihogramma cīnā pret augu kaitēkliem [Biocontrol of the Trichogramma]. Rìga: Zinātne. 41 lpp. (in Latvian).

Циновский Я. П. (1953). Насеkомые Латвийской ССР. Рогохвосты и пилильщики [Insects on Latvian SSR. Sawflies and Siricidae]. Рига: Изд-во Академии наук Латвийской ССР. 70 c. (in Russian).

Циновский Я. П. (1958а). Биологические основы установления прогноза окукливания личинок майских жуков [Biological backgrounds for prognostication on cockchafer grub pupation]. Рига: Изд-во Академии наук Латвийской ССР. 337 c. (in Russian).

Циновский Я. П. (1958b). Цитологические изменения в половых железах личинок пластинчатоусых жуков как показатели готовности к окукливанию [Citological changes in the sexual gland of larva scarabae- ids before pupation]. Труды Института биологии Академии наук Латвийской ССР, Т. 5, 5-41 (in Russian).

Циновский Я. П. (1964) Закономерности в развитии гонад щелкунов и их изменения под влиянием пестицидов [Regularities in the development of gonadal cells of the click-beetle and their changes under the influence of pesticides]. Труды Института биологии Академии наук Латвийской ССР (Фауна Латвийской ССР и сопредельных территорий), Т. 4, 3-21 (in Russian).

Циновский Я. П. (1967) Хрущи и борьба с ними [Click-beetle and their control]. Зоологический журнал, № 12, 29-34 (in Russian).

Циновский Я. П., Егина К. Я. (1959). Цитологические изменения в процессе развития гонад щелкунов (Selatosomus aeneus L., Lacon murinus L.) [Citological changes in the process of development of gonadal cells of click- beetle (Selatosomus aeneus L., Lacon murinus L.)]. Труды Института биологии Академии наук Латвийской ССР, Т. 12, 5-17 (in Russian).

Циновский Я. П., Егина К. Я. (1961а). Экология щелкунов (Selatosomus aeneus L., Agriotes obscurus L., A. lineatus L., Limonius aeruginosus L.) [Ecology of the click-beetle]. Труды Института биологии Академии наук Латвийской ССР, Т. 20, 7-32. (in Russian).

Циновский Я. П., Егина К. Я. (1961b). Определение возраста и установление прогноза окукливания личинок щелкунов (Agriotes obscurus L., Selatosomus aeneus L.) [Determination of age and prognostication of click-beetle (Agriotes obscurus L., Selatosomus aeneus L.) larvae pupation]. В кн.: Фауна Латвийской ССР, Т. 3 (с. 33-59). Рига: Изд-во Академии наук Латвийской ССР (in Russian).

Циновский Я. П., Егина К. Я. (1961c) Борьба с личинками щелкунов вредителями кукурузы [Fighting click-beetle larvae - pests of the maize]. Фауна Латвийской ССР, Т. 3 (с. 61-77). Рига: Изд-во Академии наук Латвийской CCP (in Russian).

Циновский Я. П., Чударе 3. П., Кауцис А. (1970). Ионизирующее излучение против майских жуков [Ionization radiation against cockchafers]. Лесное хозяйство, № 4, 72-73 (in Russian).

Циновский Я. П., Егина К. Я. (1966). Действие и распад апикальных клеток щелкунов [Function and necrosis of apical cells of the click beetle]. Известия Академии наук Латвийской ССР, № 6 (in Russian).

Егина К. Я., Циновский Я. П., Чударе 3. П. (1972). Рост и развитие энтомопатогенного гриба Entomophothra thaxteriana Petch на различных питательных средах [Growing and development of entomophtohral fungi Entomophothra thaxteriana Petch on various mediums]. В кн.: Патология насекомых (с. 57-71). Рига: Зинатне (in Russian).

Егина К. Я., Петрова В. И., Петров В. М., Страздыня А. А., Циновский Я. П., Чударе З. П., Якшевиц М. Р. (1976). Энтомофторовые грибы в борьбе с вредителями растений [Entomophthoral fungi in pest control]. В кн.: Химия и биология сельскому хозяйству (с. 76-78). Рига: Зинатне (in Russian).

Егина К. Я., Чударе 3. П., Страздиня А. А., Циновский Я. П., Якшевиц М. Р. (1977). Эффективность энтомофторовых грибов в борьбе с тлями и паутинными клещами [Effect of entomophthoral fungi in pest control of aphids and mite]. В кн.: Энтомопатогенные микроорганизми вредителей растений (с. 52-71). Рига: Зинатне (in Russian).

Циновский Я. П., Егина К. Я., Чударе 3. П., Страздиня А. А., Якшевиц M. P. (1977). Энтомофторозы тлей в Латвийской CCP [Entomophthorous epizootics in the Latvian SSR]. В кн.: Энтомопатогенные микроорганизми вредителей растений (с. 5-13). Рига: Зинатне (in Russian). 


\section{SAVRUPĀ CEL,A GĀJĒJS ENTOMOLOGS JĒKABS CINOVSKIS (03.02.1906-08.09.1984)}

Latvijas ZA korespondētājloceklis, biolog̣ijas zinātṇu doktors, zoologs Jēkabs Cinovskis strādāja LU (toreiz Latvijas PSR Zinātṇu akadēmijas) Bioloǵijas institūtā kopš tā dibināšanas līdz pat aiziešanai pensijā (1951-1976). Jēkabs Cinovskis Latvijā iedibināja divus nozīmīgus pētniecības virzienus — kukaiņu citolog̣iju un augu biolog̣iskās aizsardzības metožu izstrādi. Viṇa vadītās Dzīvnieku citoloğijas laboratorijas kolektīva veikto darbu pamatā bija limitējamo (augu kaitēkḷu) un ekspluatējamo (entomofāgi, entomopatogēni) mijiedarbības procesu izpēte populāciju, indivīdu un šūnu līmenī. Tādējādi J. Cinovskis savā zinātniskajā darbā pielietoja tajā laikā reti izmantotu pan̄ēmienu — daudzpusīgu pētniecību, lietojot citoloǵiskās un citokīmiskās metodes, lai izstrādātu videi draudzīgus augu aizsardzības līdzekḷus. Izcilais zinātnieks bija viens no vadošajiem Latvijas zoologiem, kura vārdu pazina ārpus Latvijas. Viņš izcēlās ar lielu strādātgribu un strādātspēju, godprātību, atbildību un, pats galvenais, pētījumu oriǵinalitāti. 